\title{
Introduction to New Thinking, New Scholarship and New Research in Catholic Education: Responses to the Work of Professor Gerald Grace
}

\section{Sean Whittle}

\section{Introduction}

Since 1997, there has been a steady growth in new thinking, new scholarship and new research about Catholic education, most of which has been influenced by the work of, and role played by, Professor Gerald Grace. This volume presents thoughtful and critical responses to Grace's work over this period. This is an important and exciting volume because it brings together a very strong collection of accomplished scholars in the field of Catholic education, from both the UK and internationally, who have taken the opportunity to engage specifically with the work and contribution of Gerald Grace. This edited collection of carefully commissioned contributions will serve as a very good introduction to Catholic Education Studies in the future because each chapter weaves together many different aspects of its history and development. This volume also provides an engaging yet critical platform from which to celebrate the work and achievement of Gerald Grace in relation to Catholic education.

Moreover, this volume provides readers with the opportunity to take stock of the current state of research into Catholic education, which has benefitted from both the writings and innovative work of Gerald Grace. The latter includes the creation of the Centre for Research and Development in Catholic Education (CRDCE) and his role as the founder and inaugural Chief Editor of the journal International Studies in Catholic Education (ISCE). Rather than engaging with all of Gerald Grace's work as an educator with a career spanning the best part of six decades, this volume puts the spotlight on his work in more recent years in relation to Catholic education. However, it will be suggested that it is in part his earlier career accomplishments that have provided an ideal basis from which to nurture the field of Catholic Education Studies both nationally and internationally.

This introduction will begin by putting Gerald Grace's work since the mid-1990s into context, before describing what he was able to achieve since the creation of the CRDCE in 1997. In this period, two notable publications stand out, but by far the most important contribution is Grace's achievement in creating the journal ISCE in June 2009. This is quickly followed by

DOI: $10.4324 / 9781003$ |7| I553-I 
his outstanding success in editing the journal for nearly fifteen years. Over this time, he has skilfully used his editorial role to nurture and promote new thinking and new scholarship in Catholic education.

\section{Context: Gerald Grace and Catholic Education Studies}

It was not until 1993 that Professor Gerald Grace turned his attention to what was happening in Catholic education. This was towards the end of what had been a successful career as an academic, working in the fields of the History and Sociology of Education. Grace worked extensively in education teaching, carrying out research and writing, and holding posts in leading institutions. These included King's College (London), the Institute of Education (London), the University of Cambridge and Durham University. He ended this part of his career as the Head of the School of Education at Durham University. He had firm plans to retire at the age of 60 at the start of 1996, with the intention of living serenely in Brighton in East Sussex. However, his plans for a quiet retirement in leafy Sussex were significantly disrupted by the stirrings that were taking place in relation to Catholic education in the early 1990s.

It was in 1993 that Grace attended a two-day seminar at St Edmund's College Cambridge, organised by his friends and colleagues Dr Terry McLaughlin and Dr Bernadette O'Keeffe. This seminar had been convened to consider the newly published work Catholic Schools and the Common Good by Anthony Bryk and his team at Chicago University. This book presented in-depth empirical research into a small number of American Catholic high schools. It was fruitful research that demonstrated how Catholic education contributes much to the Common Good of society at large. At the seminar, the scholarly excellence of the text triggered rich discussion among the participants, which also included Richard Pring from Oxford, Joseph O'Keefe SJ from Boston College and an upand-coming doctoral researcher, James Arthur. This academic gathering had a profound impact on Gerald Grace, one that he would compare to a Damascene moment that thoroughly reorientated his academic interests and passions. Grace wanted to try to emulate the achievements of Bryk's work and extend its influence beyond the USA. In effect, he had a growing conviction, that could be likened to an academic calling or mission, to develop an international field of Catholic education scholarship and research. Grace had discovered in 1993 what would be the driving passion during his retirement. In retrospect, this moment of academic conversion was the start of what has become a second academic career for Gerald Grace, which in many respects has eclipsed and surpassed his pre-retirement one.

What Grace quickly realised was that the American research provided an obvious model that could be replicated in other parts of the world, including the UK. It demonstrated the value of in-depth fieldwork analysis of even a small number of schools, as a lens for researching the religious, spiritual and social justice principles of Catholic education. In addition, access to so-called 'big data' 
was shown to be a platform for statistical co-analysis of Catholic education and state/public schools in the USA. This high-quality analysis gave the Bryk research the solid foundation to be able to argue that there is an inspirational ideology that Catholic schools share and that this is part of the forces that contribute to the overall effectiveness of Catholic schools. As his retirement project, Gerald Grace wanted to develop an international field of Catholic education scholarship and research which could aspire to reproduce some of the quality of analysis that is exemplified in the Bryk model. Grace has always argued that high-quality empirical work from the USA was his initial inspiration.

\section{Developments after 1997}

Shortly after retiring in 1996, Grace set about the founding of a Centre for Research in Catholic Education (the CRDCE) in order to give himself a research base and way of collaborating with others interested in Catholic education. To fund this centre, Grace approached a range of donors to request donations, most notably Religious Congregations with a mission or charism in education. He was successful in gaining a sufficient amount of funding and was able to keep the running costs to a minimum by being given the free use of an office at the Institute of Education (London) by the director, Professor Peter Mortimore. Grace's CRDCE received initial crucial support from two members of staff at the Institute of Education, Professor Denis Lawton and Dr Paddy Walsh. What is today the UCL Institute of Education in London, thanks to the creative leadership of Peter Mortimore, is where his mission began.

In its initial stage of development, the CRDCE concentrated upon providing material that might encourage continuous professional development (CPD) sessions in Catholic schools in the UK and Ireland. This resulted in a professional focus series of booklets, ranging from the Catholic School and the Common Good, to Can there be a Catholic Curriculum?. These were sent out to schools in the period between 1997 and 2008. The second stage was when Grace, as director of the CRDCE, secured funding to undertake fieldwork in sixty Catholic, inner-city secondary schools. This ground-breaking empirical research was published in 2002, under the title Catholic Schools: Mission, Markets and Morality, by the publisher Routledge. This book is now rightly viewed as a seminal text. It is referred to by each of the contributors to this volume. It also marked a profound shift in research into Catholic schools in the UK, which had up to this point had a low level of empirical investigation, opting instead for theological reflections or historical surveys. It set the benchmark for subsequent research into Catholic education in the UK and, as many chapters in this volume demonstrate, its influence spread far and wide. Not long after 2002, Grace's work was translated into Spanish, making it even more widely accessible, particularly in South America. Grace's 2002 study shared the same high quality that was evident in Bryk's 1993 study and this meant the scene was set to take on a more international perspective to researching Catholic education. To 
help bring this about, Grace began a collaboration with Professor Joseph O'Keefe SJ (Boston, USA). They shared the concern that international studies in Catholic education was a relatively neglected field. To begin rectifying this they established a joint research project, starting in 2001, to attempt a worldwide survey of existing Catholic education research. This took in over thirty countries and jurisdictions in the five-year project. It was apparent that research into Catholic education was beginning to emerge in many more parts of the world and that this deserved to be brought to the attention of more people. Grace and O'Keefe decided to publish a 'Handbook' that would present much of what was going on. The result was the publication of a two-volume work, published by Springer (2007), titled the International Handbook of Catholic Education. This important work helped to demonstrate that the field of Catholic Education Studies was firmly establishing itself. This was the first ever international survey of research and scholarship in Catholic education.

By 2007, the CRDCE, thanks to the dedicated hard work of Gerald Grace, had contributed two very important publications to the field and had helped to shape the nature of the research being undertaken. Grace realised that it was not occasional bigger publications that were needed but an ongoing forum for bringing together up-to-date research and scholarship. What was needed was a journal devoted to international studies in Catholic education. Grace set himself the challenge of bringing this journal into existence, basing it firmly within the CRDCE. This was an ambitious endeavour because he was calling for the first ever international journal devoted to Catholic education. It was a daunting prospect to convince the leading publisher of such journals, Routledge, to commit to such a project. Their concern was over the 'market' appeal of such a journal and if there would be sufficient interest in it. Grace successfully managed to convince them by arguing that Catholic education is, at the global level, the largest provider of faith-based education and as such there ought to be a journal that takes on an international perspective. In 2008, Routledge agreed to launch the journal with Gerald Grace being the first executive editor of International Studies in Catholic Education (ISCE). The journal began its life tentatively in 2009: it was accessed by readers in forty countries and in total there were a reported 354 full-text downloads of articles. Today, ISCE is accessed by readers in 112 countries and in excess of 17,000 full-text downloads take place annually. The journal has grown from strength to strength and this demonstrates Grace's vision and astuteness in creating it. The journal ISCE has provided a much-needed forum for educators working in schools, colleges and universities to engage in dialogue with each other internationally.

\section{The move to St Mary's University, London}

Following an invitation from the Vice Chancellor of St. Mary's University, London, in 2016 (Professor Francis Campbell), Grace moved the CRDCE and the editorial office of ISCE away from the Institute of Education to St Mary's University. Through this move, Grace was able to support the goals of this new 
university to raise its international profile. Grace was happy to do this, and he took up the honorary position to become a Visiting Professor at St Mary's. The move to St Mary's provided an opportune time to strengthen the support team for the journal, drawing on the increasing number of researchers at St Mary's who work in the field of Catholic Education Studies. In less than two decades Gerald Grace has, through the CRDCE, been able to demonstrate obvious success in fulfilling the mission he embraced following his Damascene experience back in 1993. He has made a significant contribution to international studies in Catholic education. The CRDCE has found its home in a university which aspires to be a leading and innovative Catholic university in London and the journal he created is now firmly established. All the indicators are that St Mary's is fully committed to nurturing and enhancing both the CRDCE and the journal ISCE well into the future. There is a solid legacy to Grace's work.

It is also important to appreciate that Gerald Grace has played an important role in being heavily involved in giving talks, presenting at conferences and undertaking research activity in relation to Catholic education over a sustained twenty-five-year period. This is both internationally and also throughout the UK. Over the years, his presence at a seminar or conference was enough to raise the profile of the event. He is an adept, engaging and highly entertaining speaker. Crucially, he also brings an important air of gravitas to even the humblest of seminars or conferences. Gerald's seal of approval has been important in allowing other initiatives to flourish, for example the formation of the Network for Researchers in Catholic Education (NfRCE). The emergence of this network, which grew out of the various Catholic education conferences and initiatives organised by the Jesuit-founded Heythrop Institute of Religion and Society, enjoyed the full support of the director of the CRDCE. The NfRCE, which formally began in 2016, is also an important testimony to the way in which the field of Catholic Education Studies has grown since the mid1990s throughout the UK and Ireland. There is no mere coincidence that this has been the time throughout which Grace has been hard at work bringing about his mission. He has successfully cleared the path for other researchers to enter this field of study. If it were not for Grace's work, it would be highly improbable that the NfRCE would have been able to come into existence.

\section{The structure of this volume}

There are two main parts to this book. Part I presents ten contributions from Gerald Grace's colleagues in the UK. Some are very long-standing associates, going right back to his moment of academic conversion, including those such as Professor James Arthur, Professor Richard Pring, Dr Paddy Walsh and Professor John Sullivan. Other contributors have worked closely with him particularly on editing or supporting the work of the journal ISCE, such as Dr John Lydon and Dr Ann Casson. Others have either worked alongside Gerald or been inspired by his practical encouragement and guidance; these include 
Professor Meg Maguire, Dr Helena Miller, Dr Caroline Healey and Dr Sean Whittle. In Part II of this book, there is a firmly international flavour, with a further ten contributions. This is fitting recognition that Gerald Grace's influence extends well beyond the UK. Moreover, it is a tribute to the vigour of the international scholarship in the field of Catholic Education Studies that Gerald Grace has sought to bring into dialogue. There are contributions from the USA (Professor Quentin Woden), Chile (Professor Cristobal Madero SJ), Australia (Professor Graham Rossiter), Kenya (Dr Jacinta Adhiambo), France (Professor Francois Moog), Ireland (Dr Marie Griffin), Scotland (Professor Stephen McKinney), Thailand (Dr Theresa Punnachet), Malta (Professor Mary Darmanin) and the Philippines (Joanna Oliva). Rather than presenting a summary of each of the twenty contributions here, an abstract is supplied at the start of each chapter. The final point in this introduction is to thank each of the contributors for the high quality of their chapters. Taken together, the contributions in this volume give a powerful testimony and set of reflections about the influence of Gerald Grace and the numerous ways in which he has contributed to new thinking, new scholarship and new research in Catholic education.

\section{References}

Bryk, A. et al. (1993). Catholic Schools and the Common Good. Cambridge, MA: Harvard University Press.

Grace, G. (2002). Catholic Schools: Mission, Markets and Morality. London: Routledge. Grace, G. and O'Keefe, J. (Eds) (2007). International Handbook of Catholic Education. Volumes 1 and 2. Dordrecht: Springer Publishing. 